\title{
STRATEGI COPING DALAM MENGELOLA DAMPAK PSIKOLOGIS PANDEMI PADA MASYARAKAT PERKOTAAN
}

\author{
Rahmah Hastuti ${ }^{1}$ \\ ${ }^{1}$ Program Studi Psikologi, Fakultas Psikologi, Universitas Tarumanagara, Jakarta \\ Email: rahmahh@fpsi.untar.ac.id
}

\begin{abstract}
This community service activity (abdimas) is carried out in an effort to provide knowledge sharing on the ongoing pandemic conditions. Community service activities were carried out in the form of counseling with a webinar format with 44 participants, but 14 people filled out the seminar evaluation form completely. Currently, the pandemic conditions are causing economic changes and they are psychologically affected, one of which is stress. The audience form the webinar's session need information to cope with the psychological conditions, including efforts to be able to carry out problem solving strategies called coping. However, in unfavorable conditions like today, of course, there are many risks if abdimas activities are carried out face-to-face, so that activities are carried out virtually, and broadcast by streaming on YouTube channels. From the results of this abdimas activity, participants felt the benefits and delivered positive evaluations.
\end{abstract}

Keywords: stress, coping with stress, pandemic

\section{ABSTRAK}

Kegiatan pengabdian kepada masyarakat (abdimas) ini dilakukan dalam upaya untuk memberikan knowledge sharing atas kondisi pandemi yang masih terus berlangsung. Kegiatan abdimas dilakukan dalam bentuk penyuluhan dengan format webinar dengan peserta berjumlah 44 orang, namun yang mengisi form evaluasi seminar secara lengkap berjumlah 14 orang. Peserta webinar merupakan masyarakat perkotaan yang berasal dari wilayah Cibubur, Jakarta Timur. Saat ini kondisi pandemi menyebabkan perubahan secara ekonomi dan mereka terdampak secara psikologis, salah satunya yaitu stres. Peserta abdimas memiliki kebutuhan akan dukungan informasi sehubungan dengan penguatan kondisi psikologis yang tengah mereka alami, meliputi upaya untuk dapat melakukan strategi penyelesaian masalah yang disebut coping. Namun demikian, dalam kondisi yang kurang kondusif seperti saat ini tentu terdapat banyak risiko jika dilaksanakan kegiatan abdimas dilakukan secara tatap muka, sehingga kegiatan dilakukan secara virtual, dan ditayangkan secara streaming di kanal youtube. Dari hasil kegiatan abdimas ini, peserta merasakan kebermanfaatan kegiatan abdimas dan menyampaikan evaluasi positif sebagai bentuk feedback atas kegiatan abdimas.

Kata kunci: stres, coping stress, pandemi

\section{PENDAHULUAN}

Pandemi ini membawa dampak yang sangat luas, terlebih lagi durasi pandemi ini begitu panjang dan tidak dapat dipastikan berakhirnya ditambah lagi dengan munculnya berbagai varian virus yang mengkhawatirkan masyarakat. Kemudian, dampak dari pandemi ini tentunya mengubah aturan dan kebiasaan serta pola hidup termasuk sistem kesehatan masyarakat, sistem pendidikan dan kondisi kerja. Hal ini yang mendorong kita semua untuk dapat beradaptasi dan menyesuaikan diri dengan perubahan (Hartijasti \& Waturangi, 2021).

Banyaknya orang yang mengalami permasalahan kesehatan mental akibat pandemi Covid-19 bisa dipahami mengingat pandemi Covid-19 merupakan sumber stres baru bagi masyarakat dunia saat ini. Dunia dirundung krisis kesehatan mental, karena pandemi ini terjadi di seluruh lapisan dunia berdampak pada angka kematian dan faktor risiko terpapar, kondisi di awal pandemi, membuat sebagian besar orang mengalami isolasi dan karantina, belum lagi angka kemiskinan meningkat, dan kecemasan akibat pandemi Covid-19. Dampak psikologis yang sangat dirasakan salah satunya yaitu stres (Winurini, 2020).

Stres merupakan suatu respon emosional, yang ditandai dengan adanya masalah, kemudian adanya kondisi ketidaknyamanan, karena ada kondisi kesenjangan atau ketidaksesuaian antara harapan dengan kenyataan. Masalah tidak dapat dapat kita hindari kita harus bisa menerima sebagai bagian dari hidup kita. Masalah yang ada di saat pandemi beragam. Ada keinginan untuk dapat berkumpul bersama teman-teman, bisa bekerja, namun kenyataan yang terjadi justru sebaliknya, bahkan ada yang terpaksa dirumahkan, kemudian inginnya bisa melangsungkan sekolah tatap muka, bisa 
melakukan traveling, atau hanya sekadar jalan-jalan ke mall serta ingin beribadah dengan lebih leluasa, namun realitanya semuanya dibatasi.

Berikutnya terkait dengan kondisi psikologis yang dialami oleh setiap orang di masa pandemi ini dapat berbeda-beda ada yang panik, stres dan lain sebagainya. Dampak stres bagi kesehatan seperti sakit kepala, berat badan turun, tetapi nafsu makan bertambah, kenaikan atau penurunan berat badan secara drastis, kadar kolestrol meningkat, perubahan pada kulit atau adanya masalah pada kulit, keluhan sakit pada bagian tubuh tertentu degup jantung kian cepat, tangan berkeringat, dan terkadang seseorang menjadi ceroboh karena tidak bisa mengontrol emosinya. atau bahkan psikosomatis yaitu keluhan fisik yang sebenarnya penyebabnya yaitu secara psikologis. Selain respons fisik, stres juga memiliki indikasi emosional yang punya pengaruh buruk bagi individu. Misalnya, depresi yaitu gangguan emosional ketika seorang mengalami suasana hati buruk atau mood yang rendah secara konsisten dalam jangka waktu lama. Berikutnya, ada juga kecemasan. Rasa cemas berbeda dari kondisi depresi. Kecemasan ditandai dengan perasaan khawatir berlebihan dan sedih yang persisten. Namun, seperti halnya depresi, perasaan cemas bisa jadi indikasi bahwa seseorang mengalami stres, yang dalam jangka panjang, dapat berujung ke gangguan kecemasan. Selanjutnya, dampak psikologi lainnya yitu mudah marah. Ini merupakan ciri umum orang yang mengalami stres. Sensibilitas tinggi terhadap kemarahan berkaitan erat dengan stres mental. Hal ini punya bahaya bagi fisik yang menjadi cikal bakal serangan jantung akibat stres. Selain itu, ada pula dampak berupa gangguan ingatan dan kesulitan berkonsentrasi. Stres juga ditandai dengan adanya suasana hati yang fluktuatif ( $\operatorname{mood}$ swing).

Terkait dengan dampak tersebut, maka diperlukan strategi untuk mengelola stres yang dikenal dengan coping stress. Dengan kata lain, berbagai cara yang ditempuh individu dalam menghadapi situasi stres dikenal dengan strategi coping. Cara mengelola stres yaitu terbagi atas emotion focused coping dan problem focused coping. Lazarus dan Folkman (1984 dalam Sarafino, 1994) mengemukakan dua strategi coping untuk mengatasi stres, yaitu problem-focused coping dan emotion-focused coping. Problem-focused coping ditandai dengan mengambil tindakan langsung untuk memecahkan masalah atau mencari informasi yang berhubungan dengan penanganan masalah. Sedangkan, emotion-focused coping, yaitu usaha untuk mengurangi reaksi emosional yang negatif akibat stres meskipun situasi tersebut tidak dapat diubah.

Dikaitkan dengan kondisi saat ini bahwa strategi pengelolaan emosi yang berfokus pada mengelola emosi dapat dibantu dengan aktivitas yang meningkatkan perasaan positif seperti olahraga, latihan pernafasan, berinteraksi dan tetap terhubung dengan orang lain meskipun secara virtual, karena dengan adanya teknologi saat ini memberi kemudahan untuk tetap terhubung dengan orang lain untuk mencegah diri mengalami stres. Sedangkan, strategi pengelolaan stres yang berfokus masalah yaitu berupaya untuk mencari solusi atas masalah dimulai dari mengetahui pemicu masalah, mengidentifikasi masalah yang kompleks kemudian membuat target penyelesaian dalam bentuk subgoaling atau tujuan kecil atau potongan kecil yang mampu dikerjakan atau diselesaikan. Namun demikian, coping stres dipengaruhi oleh berbagai faktor, selain sumber daya yang dimiliki individu dan pengaruh lingkungan (keadaan keuangan, keluarga, pendidikan, dan sebagainya), coping stres juga dipengaruhi oleh perbedaan individual (individual differences).

Pandemi akibat Covid-19 ini turut dirasakan oleh masyarakat perkotaan atau yang tinggal di perkotaan. Pengertian masyarakat menurut Kamus Bahasa Indonesia online (2021) yaitu, sejumlah manusia dalam arti seluas-luasnya dan terikat oleh kebudayaan yang mereka anggap sama". Kemudian, pengertian kota menurut Kamus Bahasa Indonesia online (2021) yaitu "daerah pemukiman yang terdiri atas bangunan rumah yang merupakan kesatuan tempat tinggal dari berbagai lapisan masyarakat". Kota juga memiliki makna sebagai daerah pemusatan penduduk dengan kepadatan tinggi serta fasilitas modern. Sehingga, masyarakat perkotaan yaitu masyarakat yaitu sejumlah orang yang terikat oleh kebudayaan yang mereka anggap sama yang menempati wilayah dengan kepadatan tinggi serta fasilitas modern. Oleh karena itu, perbedaan individual serta 
beragamnya corak kehidupan yang ada pada masyarakat perkotaan ini memengaruhi cara mereka dalam menghadapi stres dan dalam menggunakan strategi mengatasinya. Coping stress melibatkan suatu proses yang dilakukan individu dalam mengatasi atau menangani tuntutan internal atau eksternal, untuk mengurangi tekanan fisik maupun psikologis yang berasal dari faktor personal atau faktor situasi yang dinilai sebagai penyebab stres. Setiap orang dapat mengatasi (cope) situasi stres dengan cara yang berbeda dan dengan hasil yang bervariasi.

\section{METODE PELAKSANAAN PKM}

Salah satu upaya membantu mitra dalam memberikan saran rekomendasi atas permasalahan yang dihadapi yaitu melalui memberikan dukungan penguatan jaringan. Metode penyuluhan yang dikemas dengan format webinar dan talkshow, dalam hal ini menjadi salah satu upaya menerapkan psikoedukasi terkait dengan upaya memberikan gambaran yang lebih konkret kepada peserta yang merupakan masyarakat perkotaan, yang heterogen, terdiri dari berbagai macam suku, semuanya berkumpul menjadi satu di dalam keragaman pekerjaan dan aktivitas kesehariannya.

Ada banyak bentuk intervensi yang dapat digunakan dalam dunia psikologi, baik itu intervensi individual, kelompok, bahkan komunitas. Pada dasarnya setiap intervensi memiliki pendekatannya masing-masing. Salah satu intervensi yang dapat digunakan dalam berbagai setting dan dapat diterapkan secara individual ataupun kelompok adalah psikoedukasi.

Definisi dari istilah psikoedukasi adalah suatu intervensi yang dapat dilakukan pada individu, keluarga, dan kelompok yang fokus pada mendidik partisipannya mengenai tantangan signifikan dalam hidup, membantu partisipan mengembangkan sumber-sumber dukungan dan dukungan sosial dalam menghadapi tantangan tersebut, dan mengembangkan keterampilan coping untuk menghadapi tantangan tersebut. Psikoedukasi adalah treatment yang diberikan secara profesional mengintegrasikan intervensi psikoterapeutik dan edukasi (Lukens \& McFarlane, 2004).

Metode pelaksanaan dikemas dengan format webinar dan talkshow selama setengah hari dari pagi hingga siang hari dan dihadiri 44 peserta. Setelah kegiatan abdimas dilaksanakan, para peserta mengisi google form dengan link sebagai berikut https://forms.gle/wvTcQyDAiSZ6HuR99. Namun, hanya 14 peserta yang mengisi secara lengkap kuesioner feedback evaluasi kegiatan. Kesimpulan kegiatan dari hasil evaluasi 14 peserta merasakan manfaat dan merasakan senang mengikuti webinar.

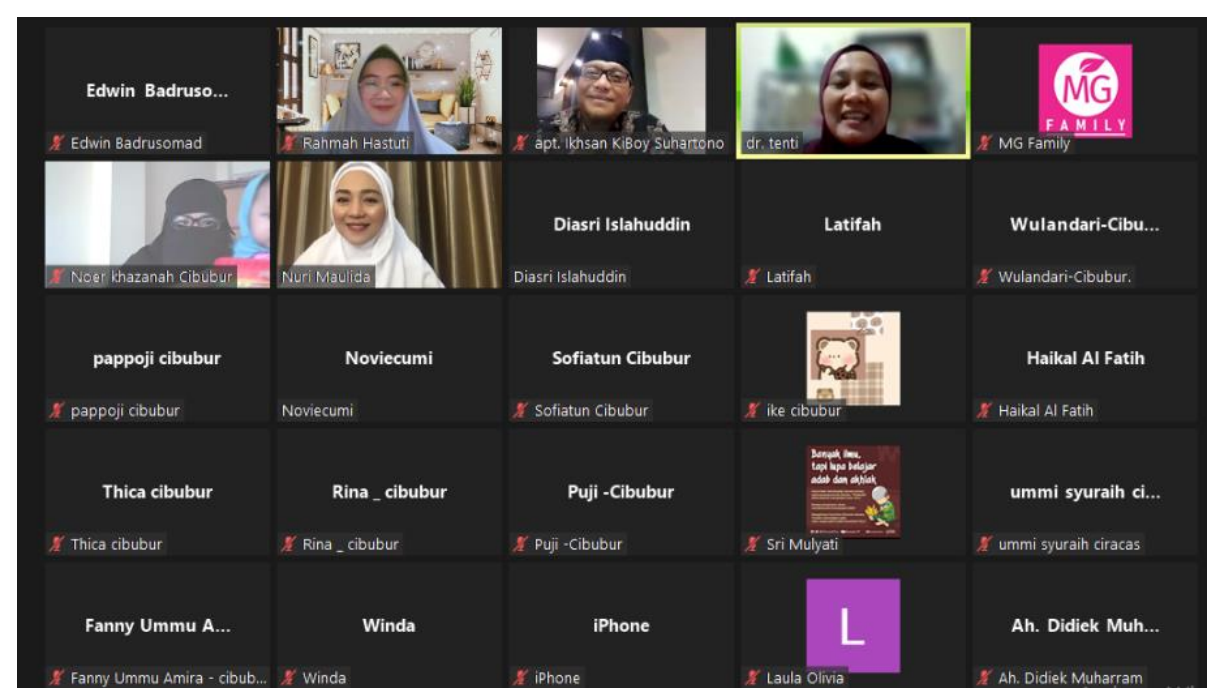

Gambar 1. Dokumentasi Kegiatan Abdimas 


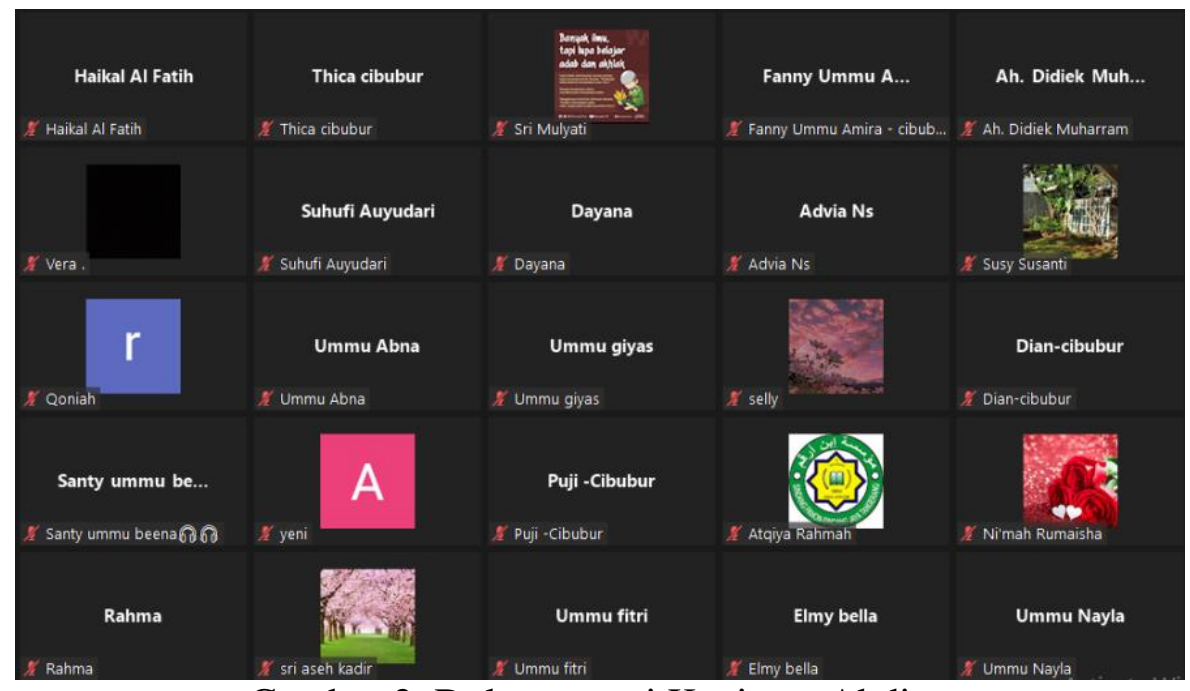

Gambar 2. Dokumentasi Kegiatan Abdimas

Terkait dengan gambaran data demografis partisipan abdimas. Berdasarkan jenis kelamin peserta dalam kegiatan pengabdian kepada masyarakat (abdimas) lebih banyak perempuan daripada lakilaki. Secara ringkas dapat dilihat pada tabel berikut ini.

\begin{tabular}{clrr}
\hline No & \multicolumn{1}{c}{ Jenis Kelamin } & Jumlah & \multicolumn{2}{c}{ Persentase } \\
\hline 1 & Laki-laki & 1 & 7.1 \\
2 & Perempuan & 13 & 92.9 \\
\hline \multicolumn{2}{l}{ Total } & 14 & 100,0 \\
\hline
\end{tabular}

Tabel 1. Gambaran Partisipan Abdimas Berdasarkan Jenis Kelamin

Berdasarkan usia dari partisipan dalam kegiatan Abdimas ini, berada pada rentang usia 32 sampai dengan 52 tahun.

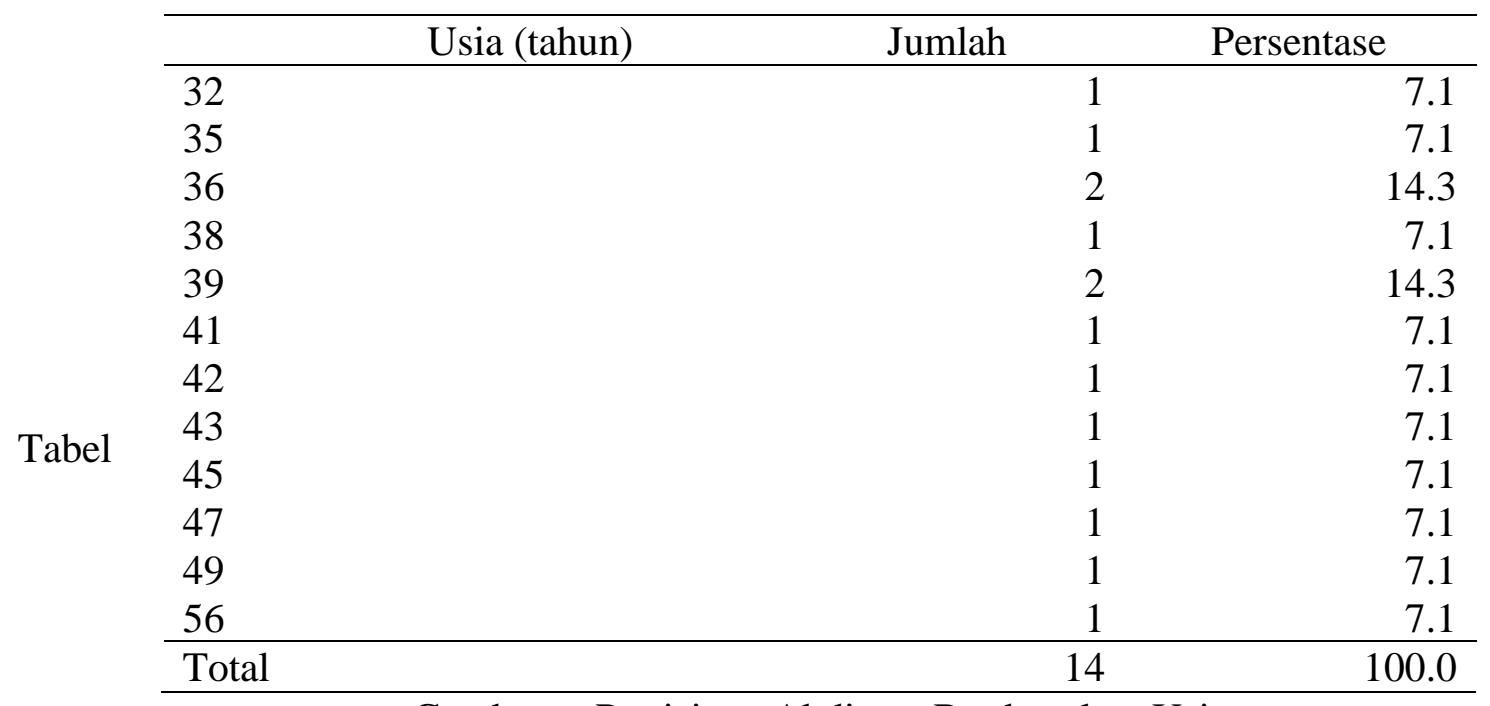

2.

Gambaran Partisipan Abdimas Berdasarkan Usia 
Di dalam kegiatan Abdimas ini, peserta mengisi form berupa evaluasi kegiatan.

\begin{tabular}{lrr}
\hline \multicolumn{1}{c}{ Feedback Abdimas } & Jumlah & Persentase \\
\hline Agar dilakukan berkala misal 6 bl atau 3 bulan sekali. & 1 & 7.1 \\
Alhamdulillah belum ada selama ini seminar spt ini. & 1 & 7.1 \\
Bagus untuk menguatkan jiwa. & 1 & 7.1 \\
Topik ini sangat berkaitan dengan kehidupan sehari hari & 1 & 7.1 \\
Maunya sih zoomnya malam, krn sudah senggang waktunya. & 1 & 7.1 \\
Menurut saya sudah bagus, sangat menginspirasi saya. Saya seperti & 1 & 7.1 \\
dicharge kembali & 1 & 7.1 \\
Sangat membantu dan berkualitas & 1 & 7.1 \\
Semoga bisa ada zoom lagi & 1 & 7.1 \\
Semoga bisa diselenggarakan sebulan sekali & 1 & 7.1 \\
Semoga diadakan setiap bulannya & 1 & 7.1 \\
Sepertinya lebih efektif malam hari & 1 & 7.1 \\
Sudah baik & 1 & 7.1 \\
Tetap semangat berbagi ilmu & 1 & 7.1 \\
Waktunya kurang lama & 14 & 100.0 \\
\hline Total & & 1 \\
\hline
\end{tabular}

Tabel 3. Evaluasi Kegiatan Abdimas

Berikutnya dilakukan analisis multiple response atas jawaban peserta abdimas terkait pertanyaan dampak dari pandemi yang dirasakan oleh partisipan. Dari respon yang disampaikan peserta abdimas

\section{dampak Frequencies}

\begin{tabular}{llrrr}
\hline & & & & \multicolumn{1}{c}{$\begin{array}{c}\text { Percent } \\
\text { of Cases }\end{array}$} \\
\hline & & $\mathrm{N}$ & Percent & $\mathrm{N}$ \\
\hline $\begin{array}{l}\text { dampak } \\
\text { pandem } \\
\text { i(a) }\end{array}$ & kesehatan & 2 & $10,5 \%$ & $14,3 \%$ \\
\hline & ekonomi & 7 & $36,8 \%$ & $50,0 \%$ \\
\hline & $\begin{array}{l}\text { perubahan_pola_hid } \\
\text { up }\end{array}$ & 1 & $5,3 \%$ & $7,1 \%$ \\
\hline & $\begin{array}{l}\text { sibuk_menjadi_guru } \\
\text { di_rumah }\end{array}$ & 2 & $10,5 \%$ & $14,3 \%$ \\
\hline & stres & 2 & $10,5 \%$ & $14,3 \%$ \\
\hline & mobiltas_berkurang & 4 & $21,1 \%$ & $28,6 \%$ \\
\hline tetap_bersyukur & 1 & $5,3 \%$ & $7,1 \%$ \\
\hline Total & & 19 & $100,0 \%$ & $135,7 \%$ \\
\hline
\end{tabular}

a Dichotomy group tabulated at value 1 .

Tabel 4. Dampak Pandemi Menurut Peserta Abdimas 
Berdasarkan respon yang disebutkan peserta abdimas lebih banyak yang menyebutkan mengenai permasalahan ekonomi. Hal tersebut didasari respon peserta abdimas yang mengakui bahwa terdampak akibat pandemic ini sehingga mereka kesulitan secara finansial. Respon di dalam tabel terkait dampak pandemi merupakan hasil coding atas respon spesifik yang disebutkan peserta abdimas.

Peserta abdimas juga telah berupaya mengatasi permasalahan yang mereka alami selama masa pandemi. Berikut adalah upaya coping stress yang dilakukan.

\section{Coping Frequencies}

\begin{tabular}{|c|c|c|c|c|}
\hline & & \multicolumn{2}{|c|}{ Responses } & \multirow{2}{*}{$\begin{array}{c}\text { Percent of } \\
\text { Cases }\end{array}$} \\
\hline & & $\mathrm{N}$ & Percent & \\
\hline $\begin{array}{l}\text { Strategi } \\
\text { coping( } \\
\text { a) }\end{array}$ & emotion_fc_semangat & 1 & $3,3 \%$ & $7,1 \%$ \\
\hline & emotion_fc_ikhlas & 1 & $3,3 \%$ & $7,1 \%$ \\
\hline & problem_fc_ikhtiar_berusaha & 5 & $16,7 \%$ & $35,7 \%$ \\
\hline & emotion_fc_positive_thinking & 3 & $10,0 \%$ & $21,4 \%$ \\
\hline & problem_fc_fleksibel_menerima_pekerjaan & 2 & $6,7 \%$ & $14,3 \%$ \\
\hline & emotion_fc_berdoa & 3 & $10,0 \%$ & $21,4 \%$ \\
\hline & emotion_fc_sabar & 3 & $10,0 \%$ & $21,4 \%$ \\
\hline & emotion_fc_beribadah & 1 & $3,3 \%$ & $7,1 \%$ \\
\hline & emotion_fc_olahraga & 1 & $3,3 \%$ & $7,1 \%$ \\
\hline & emotion_fc_menjaga_prokes & 1 & $3,3 \%$ & $7,1 \%$ \\
\hline & emotion_fc_menerima_kenyataan & 2 & $6,7 \%$ & $14,3 \%$ \\
\hline & emotion_fc_bersyukur & 4 & $13,3 \%$ & $28,6 \%$ \\
\hline & menaikkan_imunitas_tubuh & 2 & $6,7 \%$ & $14,3 \%$ \\
\hline & emotion_fc_bersedekah & 1 & $3,3 \%$ & $7,1 \%$ \\
\hline Total & & 30 & $100,0 \%$ & $214,3 \%$ \\
\hline
\end{tabular}

a Dichotomy group tabulated at value 1 .

Tabel 5. Upaya Coping yang Dilakukan

\section{KESIMPULAN DAN SARAN}

Dari hasil psikoedukasi dalam laporan Abdimas ini, ada beragam metode untuk menilai persepsi, masing-masing dengan kekuatan dan keterbatasan dan berguna untuk tertentu tujuan. Pada kegiatan abdimas ini, ada beragam strategi coping yang digunakan pada peserta abdimas. Kemudian, pengelolaan stres yang digunakan secara umum berpusat pada emosi, karena partisipan abdimas menggunakan jenis pengelolaan stres dengan melakukan pengendalian emosi, berusaha mengurangi tekanan emosional, namun tanpa mengubah kondisi objektif dari permasalahan yang ada. Terdiri dari resignes acceptance (menerima kondisi yang ada) (Lazarus \& Folkman, 1984, dalam Sarafino, 1994). Dengan hasil pengolahan data bahwa terdapat gambaran bahwa kegiatan ini dirasakan bermanfaat bagi peserta. Pada umumnya, abdimas ini dapat menjadi saluran untuk membagikan informasi untuk meningkatkan wawasan pengetahuan, khususnya bagi setiap pihak yang 
memerlukan. Dengan adanya abdimas yang membahas mengenai coping stres, sebagai salah satu upaya knowledge sharing kepada public mengenai berbagai upaya yang dilakukan ketika individu menghadapi, mengatasi ataupun menanggulangi (cope) stres. Terlebih lagi stress tersebut terjadi di masa pandemic yang durasi waktunya tidak dapat diprediksi berakhirnya. Melalui kegiatan abdimas ini diharapkan dapat menjadi bekal yang bermanfaat bagi para pada khususnya serta untuk pihak mitra pada umumnya. Melalui jalinan kemitraan antara perguruan tinggi dan pihak terkait yang mewakili elemen di masyarakat, maka terbina komunikasi dan kerjasama yang baik sehingga diharapkan mampu menjadi simbiosis mutualisme atau kerjasama yang saling menguntungkan bagi kedua belah pihak.

\section{Ucapan Terima Kasih (Acknowledgement)}

Kami tim pelaksana Abdimas mengucapkan terima kasih atas dukungan berbagai pihak hingga dapat terlaksananya Abdimas ini. Terima kasih atas dukungan dan fasilitasi dari pihak mitra PT SEI yang menjadi distributor produk kesehatan dengan brand X. Berikutnya, kepada tim pelaksana, dalam hal ini asisten lapangan, Chandra Susanto, S.Psi., yang membantu dalam menyiapkan perangkat untuk mengumpulkan data.

\section{REFERENSI}

Hartijasti, Y., \& Waturangi, D. E. (2021). Tangguh di tengah pandemic: Belajar dari Bakteri. Brave Inti Gagasan.

Kamus Bahasa Indonesia. (2021). Diunduh dari https://www.kbbi.co.id/arti-kata/masyarakat

Lukens, E. P., \& McFarlane, W. R. (2004). Psychoeducation as evidence-based practice: Consideration for practice, research, and policy. Journal Brief Treatment and Crisis Intervention, 4. Oxford University Press.

Santrock, J. W. (2011). Educational psychology (5 ${ }^{\text {th }}$ ed.). McGraw Hill.

Sarafino, E. P. (1994). Health psychology: Biopsychosocial interactions (2nd ed.). John Wiley \& Sons, Inc. Winurini, S. (2020). Permasalahan kesehatan mental akibat pandemi covid-19. Info Singkat: Kajian singkat terhadap informasi aktual dan strategis, 7(15). Pusat Penelitian Badan Keahlian DPR RI. Retrieved from http://puslit.dpr.go.id ISSN 2088-2351

World Health Organization. (2020). Q\&A on coronaviruses (covid-19). Retrieved from https://www.who.int/emergencies/diseases/novel-coronavirus- 2019/question-and-answershub/q-a-detail/q-a-coronaviruses 
Seminar Nasional Hasil Penelitian dan Pengabdian Kepada Masyarakat 2021

Pengembangan Ekonomi Bangsa Melalui Inovasi Digital Hasil Penelitian dan

Pengabdian Kepada Masyarakat

Jakarta, 21 Oktober 2021

(halaman kosong) 